\title{
The Governance of Muhammadiyah Business Charitable Based on Information Systems Management
}

\author{
$1^{\text {st }}$ Wandy Zulkarnaen \\ Universitas Muhammadiyah Bandung \\ STIE Muhammadiyah Bandung \\ Indonesia \\ wandy.zulkarnaen@gmail.com
}

\author{
$2^{\text {nd }}$ Yayan Sofyan \\ Universitas Muhammadiyah Bandung / \\ STIE Muhammadiyah Bandung \\ Indonesia
}

\author{
$3^{\text {rd }}$ Indra Sasangka \\ Universitas Muhammadiyah Bandung / \\ STIE Muhammadiyah Bandung \\ Indonesia
}

\begin{abstract}
The purpose of this study is to conduct an ongoing study of governance of Muhammadiyah's Business Charities, essentially, qualitatively, which can provide an overview of business problems that can be managed more effectively and efficiently using Management Information Systems. In this study based on the type of analytical descriptive research by collecting and recapitulating data that is not only recorded in the form of numbers but clearly and profoundly explained about the problems and needs of the organization in this case the Regional Leader of Muhammadiyah Bandung in managing and overseeing all business charities effectively, efficiently, sustainably and grow. The data collection technique was carried out by direct observation to various Muhammadiyah business charities spread in 20 sub-districts in the city of Bandung. Based on a management information system that includes an organizational profile, also a profile of the Branch Manager and Muhammadiyah Charitable Enterprises in the city of Bandung. Making Muhammadiyah Website as Association information source. Also arranged and recorded various Association activities through Photo and Video activities. Development of business networks with parties who work together in the field of information technology, libraries and online media in the context of expanding Persyarikatan propaganda. Able to optimize cadre resources in the field of information technology with commitment and professionalism in strengthening and expanding Islamic da'wah.
\end{abstract}

Keywords-Governance, Muhammadiyah,

Business Charitable, Information Systems Management

\section{INTRODUCTION}

In the era of the industrial revolution 4.0 now, many benefits are obtained from technology that continues to develop with sophisticated. It's not just gadgets that are developing, businesses, or charities that are also developing. People are increasingly helped in running successful organizations or businesses. For example, many businesses are facilitated by the technology they have.
The dynamics of the growth of Community Organizations (CSOs) that are quite high in Indonesia are the traffic of CSO activities in public spaces so as not to intersect.

The Ministry of Home Affairs canceled the data of CBOs until April 24, 2018, receiving 378,676 CBOs. Muhammadiyah as one of the largest mass organizations in Indonesia was established in Kampung Kauman Yogyakarta, on November 18, 1912, by a man named Muhammad Darwis, later known as KH. A Dahlan. He was an employee of the sultanate of Yogyakarta as a Khatib and as a trader. Seeing the state of the Islamic ummah at that time in a state of old-fashioned, frozen, and full of mystical practices, he was moved to push them back to new Islamic teachings based on the Qur'an and the Hadith. Therefore he gave an understanding of religion in his home amid his preoccupations as preacher and traders.

Management is an activity that is needed in life. From individuals, related organizations, to organizations that require complicated management, so that they are organized and well-controlled.

Muhammadiyah as one of the largest community organizations in Indonesia has 14 types of business charities with total assets of 9,586 schools/pesantren, 2,119 hospitals, 454 homes/repairs, 11,198 mosques/prayer rooms with 20,945,504 $\mathrm{m} 2$, business charities are also taken for very da'wah suitable for Muhammadiyah.

From the data on the number of charities in Muhammadiyah above it is needed in a system that can be provided in an efficient, effective and sustainable organization and organization in good growth as a form of material and spiritual accountability to the people who have given the mandate to Muhammadiyah.

By using Management Information Systems we can conduct organized discussions for the organization's 
management information needs in each assessment for operational, battle, and strategic decision making. The workings of Management Information Systems, which start from data processing and then stored in a centralized database where it can be accessed and updated to be processed and used optimally by managers who have authority in accordance with organizational goals. In addition to the leadership, all data collected can be taken as an important source of information in the decision-making process.

Muhammadiyah has various business charities. Besides being made to improve the organization, charity is also made as a way of preaching that is very suitable for Muhammadiyah. Structurally, the charity business in the coordinated area of the Regional Leadership Council of Muhammadiyah (PDM) in the city of Bandung consists of 38 schools ranging from kindergarten to tertiary institutions, 8 orphans and nursing homes, 24 mosques, 6 commercial establishmentshttps://translate.google.com/?hl=id\&tab=TT \&authuser $=0$ with 5 commercial buildings/halls which are spread in 20 Muhammadiyah Branch Managers at the District level.

Of course, a managerial system is needed in the Governance system is Muhammadiyah's internal regulations that govern several things that are agreed upon: first, organization and governance, organizational structure regulation, work procedures, logistical function grouping, direction and development of human resources, and financial support. Second, accountability, discuss policies, regulations/procedures, media accountability, and periodization of program, activity, and financial responsibilities in order to achieve the stated goals. Third, it was agreed, by applying the principle of openness which was built on the basis of obtaining information for the needy. Furthermore, for all charities to be managed optimally, an information system management based management model is needed that prioritizes the principles of approval, accountability, responsibility, fairness, and independence.

\section{RESEARCH PURPOSES}

- Knowing, analyzing and reviewing the Muhammadiyah's Charitable Business Governance model that is currently running in the PDM area of Bandung;

- Knowing, analyzing and studying the model of Muhammadiyah's Charitable Enterprises that is more effective and efficient based on Information Systems Management in the PDM area of Bandung;

- Knowing, analyzing, and studying the development of Muhammadiyah's charity business management model based on Information Systems Management in the PDM area of Bandung.

\section{RESEARCH METHODS}

In this study based on the type of analytical descriptive research by collecting and recapitulating data that is not only recorded in the form of numbers but clearly and profoundly explained about the problems and needs of the organization, in this case, the Regional Leader of Muhammadiyah Bandung in managing and overseeing all business charities effectively, efficiently, sustainably and grow.

The data collection technique was carried out by direct observation of various Muhammadiyah business charities spread across 20 sub-districts in the city of Bandung, which was the object of research by the researchers themselves, assisted by research members, as well as collecting data/information related to research material. In addition, data collection is also carried out through structured interviews to capture information that cannot be obtained through observation.

\section{LITERATURE REVIEW}

\section{A. Governance}

Governance cannot be separated from the basic principles of good organization, namely transparency, participation, and accountability as the main elements. The term good governance is not yet standard, but there have been many definitions that try to dissect the meaning of good governance. However, there is no denying that good governance has been considered as an important element to guarantee national prosperity. By increasing accountability, reliability (reliability), policy making in government organizations, corporations (private sector), even in civil society organizations. [1]

The Canadian International Development Agency defines that good governance is reflected if the power of the organization/government is carried out effectively, fairly (equitable), honest, transparent, and accountable. Meanwhile the UN Development Program (UNDP) in 1997 put forward 8 (eight) principles of good governance namely:

- Equality to participate in policy making

- Responsibility for stakeholder needs (responsiveness)

- The ability to mediate differences between stakeholders to reach mutual consensus.

- Accountability to stakeholders served.

- Transparency in the policy making process

- Activity is based on rules / legal framework.

- Have a broad and long-term vision to improve the governance process that ensures the sustainability of social and economic development.

- Guarantee of the right of all people to improve their standard of living through equitable and inclusive means.

According to the Information Technology Governance (ITG) Institute theory [2] which defines ITG as a set of responsibilities and actions taken by the senior management of an organization, which includes leadership, structure and organizing processes ensure that the Information Technology used supports and enhances strategies and organization goals. 


\begin{tabular}{|c|c|c|c|c|c|c|}
\hline \multicolumn{7}{|c|}{ GOVERNANCE STRUCTURE MODEL } \\
\hline \multicolumn{2}{|c|}{ CLANS } & \multicolumn{2}{|c|}{ VALUE } & \multicolumn{3}{|c|}{ SYMBOLS } \\
\hline \multicolumn{2}{|c|}{ PLANNING } & \multicolumn{4}{|c|}{ CYBERNETIC CONTROLS } & \multirow[b]{2}{*}{$\begin{array}{l}\text { REWARD AND } \\
\text { COMPENSATIOI }\end{array}$} \\
\hline $\begin{array}{l}\text { LONG RANGE } \\
\text { PLANNING }\end{array}$ & $\begin{array}{c}\text { ACTION } \\
\text { PLANNING }\end{array}$ & BUDGETS & $\begin{array}{l}\text { FINANCIAL } \\
\text { MEASUREMENT } \\
\text { SYSTEMS }\end{array}$ & $\begin{array}{l}\text { NON FINANCIAL } \\
\text { MEASUREMENT } \\
\text { SYSTEMS }\end{array}$ & $\begin{array}{c}\text { HYBRID } \\
\text { MEASUREMENT } \\
\text { SYSTEMS }\end{array}$ & \\
\hline \multicolumn{7}{|c|}{ ADMINISTRATION CONTROL } \\
\hline GOVERNANCE & RUCTURE & ORGANISA & IION STRUCTURE & POLIC & CIES AND PROCED & URES \\
\hline
\end{tabular}

Fig. 1. Governance Structure Model

\section{B. Muhammadiyah's Charitable Enterprises}

Muhammadiyah has various business charities. Besides being used to grow the organization, business charity is also used as a way of preaching that is very suitable for Muhammadiyah. However, not all charity businesses owned by Muhammadiyah are held by Muslims. A small percentage employ non-Muslim communities.

According to the Deputy Chairperson of the Muhammadiyah Community Empowerment Council, Ahmad Ma'ruf said, the Muhammadiyah's charitable efforts were indeed based on Islam. However, that does not mean Muhammadiyah must employ all its workers from Muslims. "Charitable businesses owned by Muhammadiyah must be based on service duties. Likewise, providing the best service to the community, so that not all must be from Muslim workers," Ma'ruf said on Thursday. He explained, certain business charities, such as in Kupang there are Muhammadiyah schools that not all workers and students are filled by Muslims. The reason is, in Kupang there are still few Muslims. For this reason, in order to run the charity business, anyone can fill every part of the charity business as long as they work well. [3]

Likewise, to become a leader in a charity business, those who are non-Muslims can be the leaders of the Muhammadiyah business charity. Moreover, Muhammadiyah's charitable endeavors are mostly found in areas where there are few Muslims.

\section{Information Systems Management}

The need for a management information system at this time is absolute, because the need for information that is obtained quickly and precisely is needed by humans who currently tend to be mobile with ease in accessing data and information needed right away.

Management of Information Systems makes it possible to answer these challenges. This is part of the value of a management information system compared to the information that has not been integrated and managed with a single unit in a program or application.

Jogiyanto (2003: 66) argues that decision making (decision making) is a management action in choosing alternatives to achieve goals. Management as a decisionmaking tool, based on various activities, is analyzed and made a decision to be determined by management. [4]
Wikipedia (2010) defines Information Technology is the result of human engineering of the process of delivering information from the sender to the recipient so that the information will be sent faster, wider distribution, and longer storage. Meanwhile according to [5] defines Information Technology as all forms of technology applied to process and transmit information in electronic form. References [6] convey that Information Technology includes hardware and software to carry out one or a number of data processing tasks, such as capturing, transmitting, storing, retrieving, manipulating or displaying data. The definition of governance according to [7] is about how the organization believes that the strategy has been implemented, monitored and accepted the results.

Furthermore, ITG integrates and institutionalizes good practices in planning and organizing, obtaining and implementing, delivering and supporting, and monitoring IT performance to ensure that the organization's information and applied technology support organizational goals. Gaynor (in [8]) argues that ITG allows organizations to generate maximum profits from the information they have, by maximizing profits, taking advantage of opportunities and gaining competitive advantage.

Lainhart (in [8]) argues that the function of ITG is almost the same as organizational governance (Corporate Governance), although ITG is more focused on information technology. Like an organization itself, IT itself can be managed by taking good actions. For IT, these actions are structured to ensure that the organization's information technology resources are used responsibly, the risks are well managed and the information and technology tools support the organization's goals.

According to Rau [9], the word "governance" means the method used by the organization to ensure that the strategy has been implemented, monitored, and accepted the results. When this governance is applied to IT, effective IT governance is about how senior management interacts and communicates with the Head of IT to ensure that IT investments enable the acceptance of organizational strategies effectively and efficiently.

Peterson [8] argues that ITG is a complex system, which involves different business and IT stakeholders with specific perceptions, views, goals, and motivations. Each stakeholder has an interest and gives different limits on information 
technology. References [8] argues that ITG is a structure that connects information technology processes, resources, and information towards the organization's strategy and objectives to direct and control the organization in achieving its organizational goals and strategies. So the model of governance based on Information Systems Management (IT Governance), provides guarantees of efficiency and effectiveness of organizational processes that enable organizations to gain full advantage over information, maximum profits, capital, opportunities as well as competitive advantages in competing. Now, Website-based Information System Management is an information system site page that can be accessed quickly. This website is based on the development of information and communication technology which is a network of interrelated computers. Networks known as the internet are constantly becoming electronic messages, including e-mail, file transmission, and two-way communication between individuals or computers. [10]

\section{DISCUSSION}

The results of observations and analysis of Muhammadiyah's charitable business governance model based on Information Systems Management in the PDM area of Bandung through interviews and direct observation on the SICARA (Sistem Cabang Ranting) application page, data obtained as follows :

\section{SICARA (Sistem Cabang Ranting) Application Analysis} https://SICARA.id/ [11]

\section{SITE}

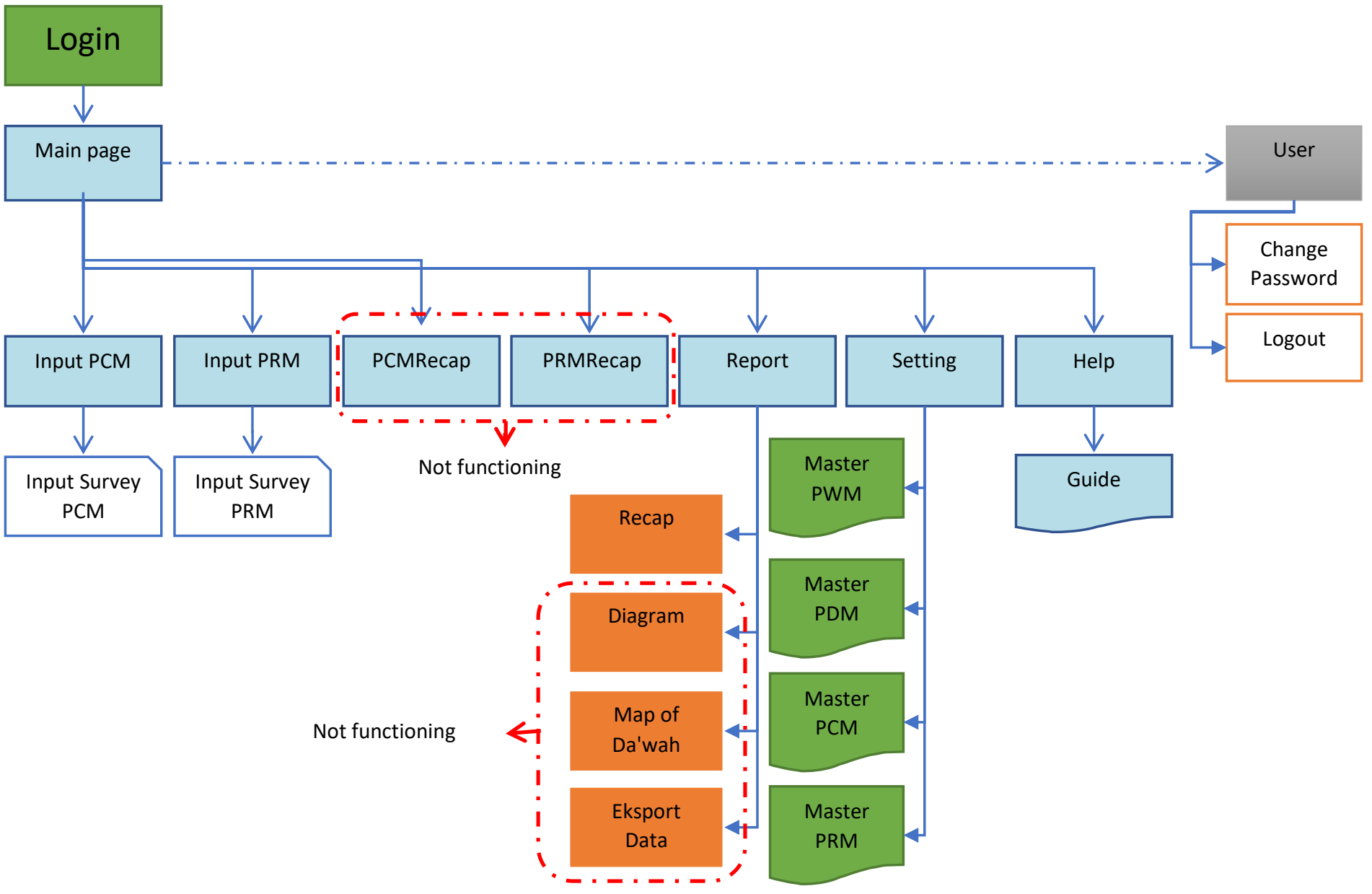

Fig. 2. Site Map 


\section{SICARA (Sistem Cabang Ranting) Application}

The Speech Application is a program developed by the LPCR (Branch and Branch Empowerment Institution) to map Muhammadiyah Branches and Branches in the context of accelerating the mapping of branches and branches of Muhammadiyah in accordance with the mandate of the 46th Congress.
In the output of the SICARA application, a mission map consists of Muhammadiyah Branch Managers, Muhammadiyah Branch Leaders, Activity Scoring for each PCM and PRM, Geographical Locations for PCM and PRM geographical locations, Deliberation, Office Ownership, Study, Study Places, Muhammadiyah Voice Subscriptions, Voice of Muhammadiyah Subscriptions. [12]

C E Secure https:/iwww.sicara.ld

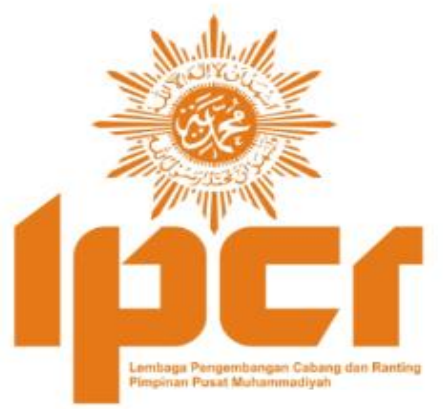

Fig. 3. Main Display

- Secure https://www.sicara.id/login

\section{E-Mail Address}

Password

Remember Me

Login Forgot Your Password?

Fig. 4. Login page 
E. SICARA Application Dashboard

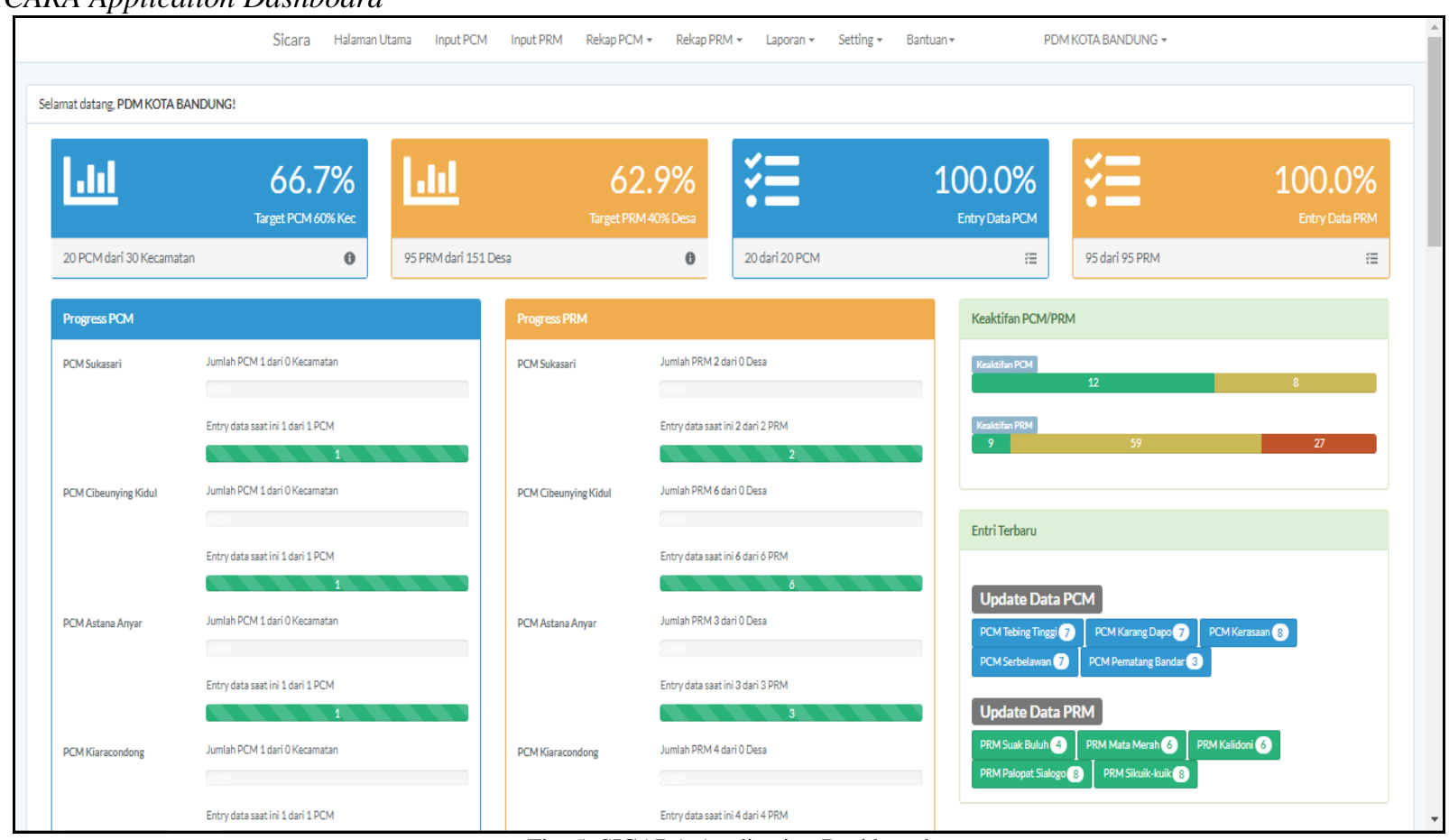

Fig. 5. SICARA Application Dashboard

To be able to access the SICARA Dashboard application, as shown above, you must first log in using the email and password that have been registered with PP Muhammadiyah's LPCR admin. On this main page available menus that can be used, namely:

- PCM input

- PRM Input

- $\quad$ Reports $\rightarrow$ Recap

- Settings

As for the other menus at this time it doesn't work so it can't be used. The dashboard also displays the following entry results:

- Comparison of the number of PCMs with districts nationally

- Comparison of the number of branches with the village nationally
- $\quad$ ercentage of PCM data that is inputted

- Percentage of PRM data inputted

- Achievement of the Amount of PCM and Input of PCM data per region

- Progress in Achieving Total PRM and Input of PRM data per region

- Recap the number of active PCM and PRM nationally

- $\quad \mathrm{PCM} / \mathrm{PRM}$ input realtime data.

F. $\quad$ Fitur Aplikasi SICARA

1. Setting Master Data

Used to edit location data in accordance with the level starting from the location of the PWM, PDM, PCM to PRM.

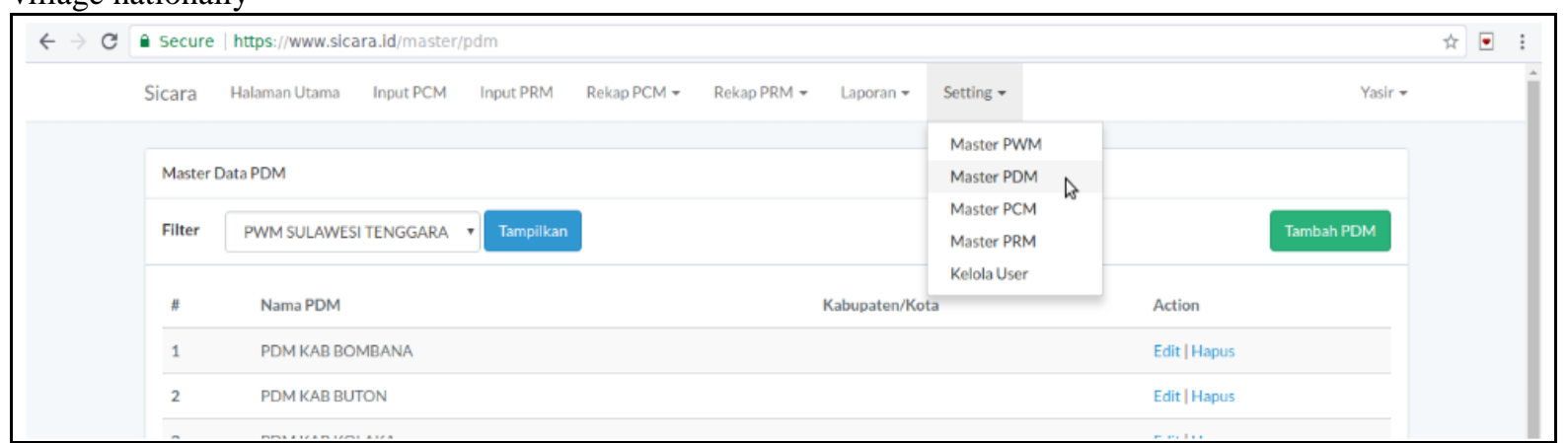

Fig. 6. Setting Master Data 


\section{Input PCM Data}

Used to select PCM data to be inputted into and then refer to the questionnaire page that contains questions in the form of fields.

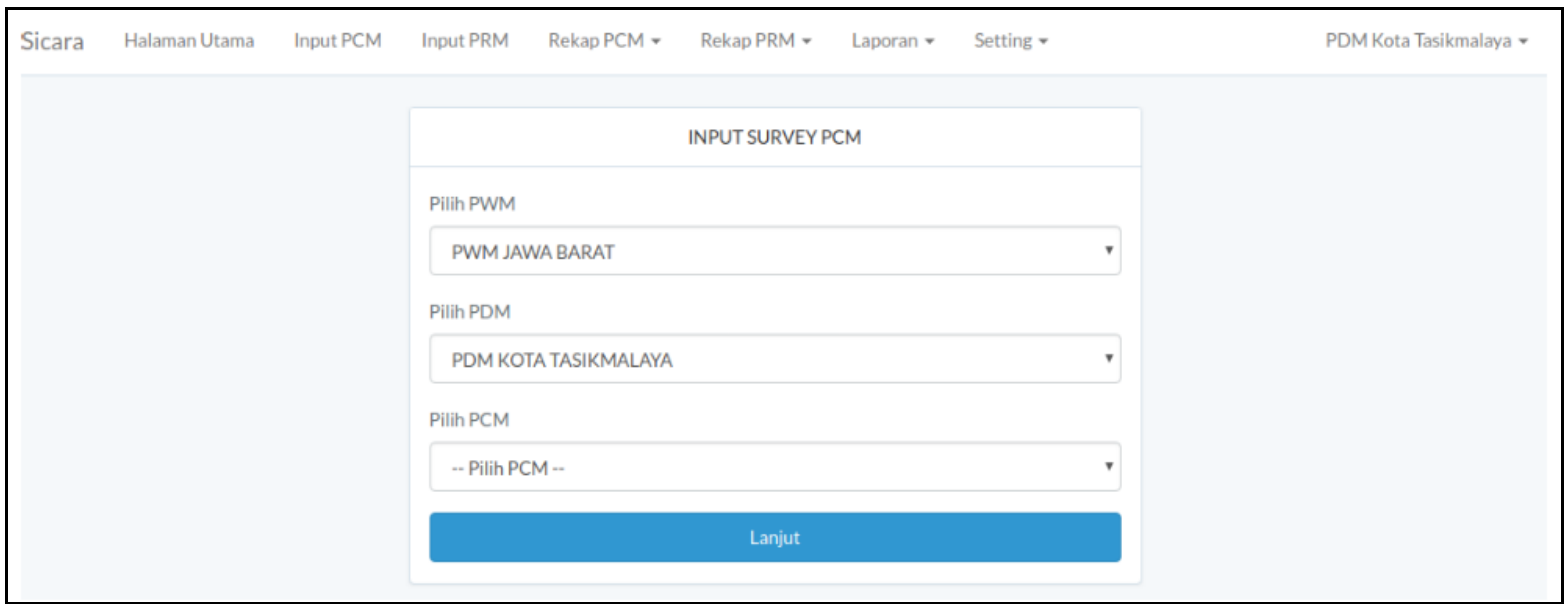

Fig. 7. Input PCM Data

\section{Input PRM Data}

Used to select PRM data for which data will be inputted and then directed to the questionnaire page that contains questions in the form.

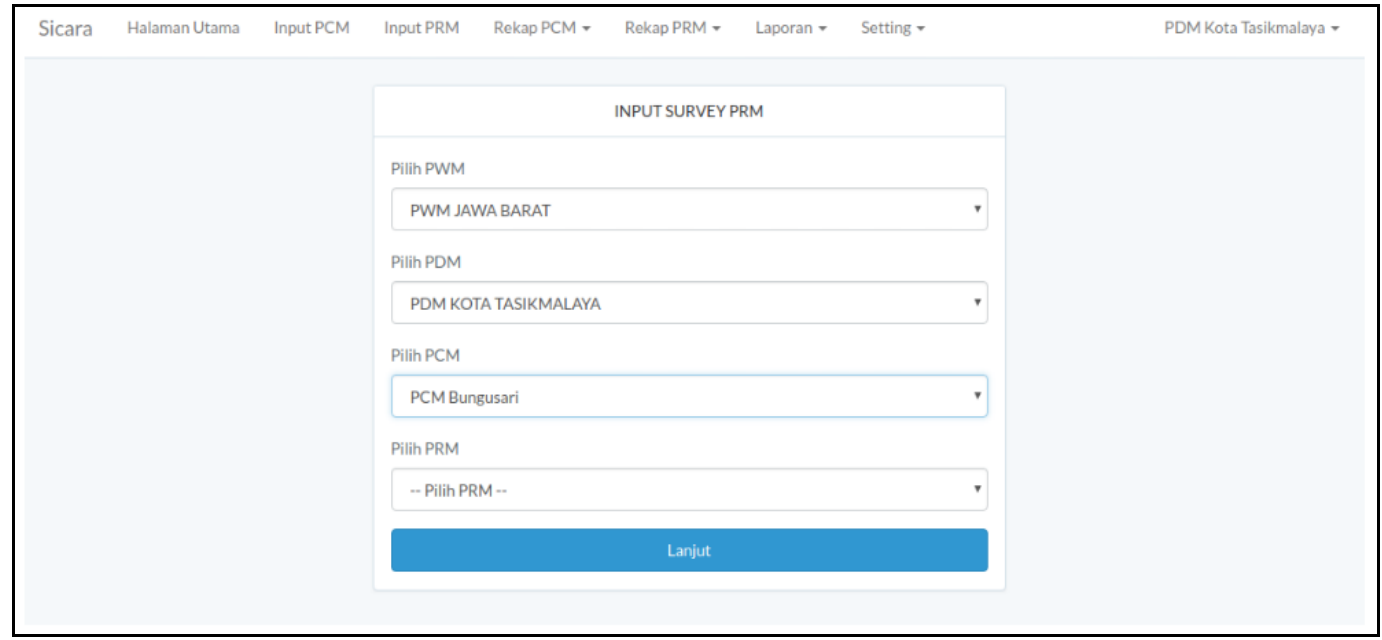

Fig. 8. Input PRM Data

\section{Reports}

On the Report Menu, there is a recap feature that is used to view the output of the results of questionnaire data processing based on the form inputted in the PCM Data Input and PRM Data Input menus. In this feature you can select the report that you want to display according to the available list, namely :

- Comparison: to see the comparison of the number of districts, villages, and PCM and PRM

- $\quad$ PCM : list of PCM scores and color indicators
- $\quad$ PRM : list of PRM Scores and color Indicators

- Scoring: graph for the scores and activeness of each PCM and PRM

- Geographic Location : graphs for the geographical location of PCM and PRM

- Musyawarah : graph for the recap of the last year of Muyscab and Musyran

- Office: chart for the ownership status of the PCM and PRM secretariat offices 
- Review : graph to display Recitation in PCM and PRM

- Mubaligh : a chart to display the number of Preachers, Preachers Corps, and Preachers Course in PCM and PRM
- Place of Worship: this menu is a chart of the mosque's mosque ownership in PCM and PRM

- SM Subscriptions: a chart to see the number of SM subscriptions on PCM and PRM. [13]

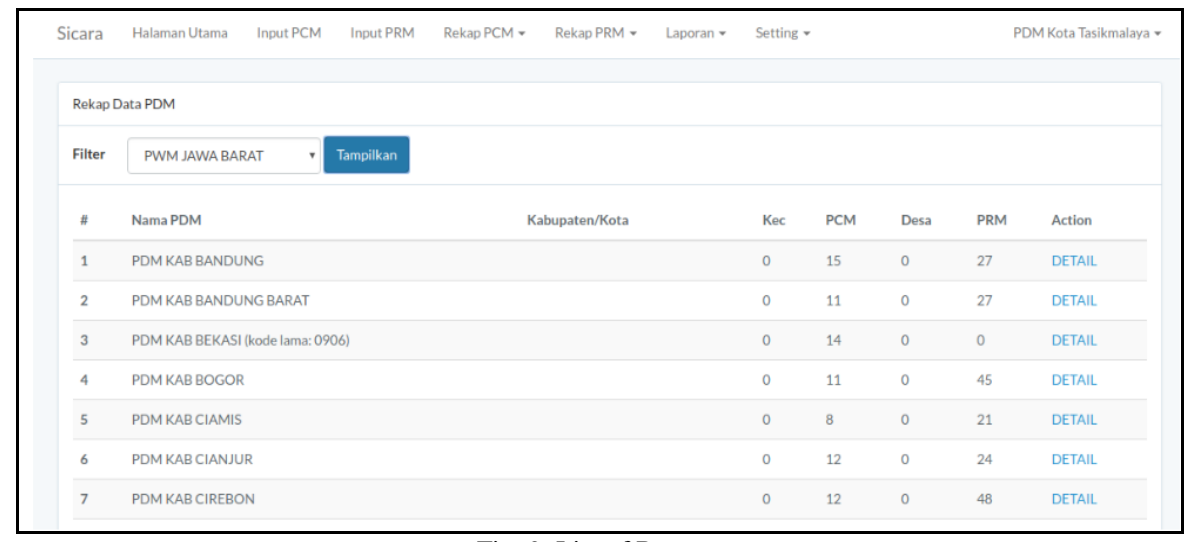

Fig. 9. List of Reports

5. Advantages of SICARA Application

- User Friendly, even though users who have just opened the SICARA Application will have no difficulty operating this application.

- The appearance is simple with all menus displayed at the top so it won't be confusing.

- The application is quite light and does not require a long time for loading data.

- The output generated in the form of numbers and graphics is generally good and can present an actual mapping report on the condition of Branches and Branches.

- Important points needed in mapping branches and branches as the main purpose of this application can be represented.

6. Lack of SICARA Application

- The application is not perfect and is still under development so some of the menus that are displayed cannot be used.

- There is no means to convey updated information related to the development of Branches and Branches.

- The latest entry information displayed on the dashboard cannot be clicked to find out what data updates have changed.

- List of Questionnaires containing questions in PCM Data Input or PRM Data is still limited so it does not adequately describe the actual condition of Branches and Branches.

- Information generated from the SICARA application data processing cannot be used as a reference for decision making because there are still shortcomings, including: the level of accuracy that has not been tested, the data is incomplete and inadequate, not up to date, there is no historical data to compare, etc. [14]

\section{CONCLUSION}

- $\quad$ The SICARA application developed by the LPCR in general is quite good at mapping the Branches and Branches of Muhammadiyah to be used as a governance model for Muhammadiyah's Business Charities that is currently running in the PDM area of Bandung.

- There is still a lot that needs to be developed so that the output generated from the SICARA application can be used as a reference in making decisions / policies, so that it can be used as a model for the management of Muhammadiyah's Business Charities which is more effective and efficient based on Information Systems Management in the PDM area of Bandung.

- $\quad$ LPCR as the owner and manager of the SICARA Application must consistently carry out updates and development so that the main purpose of Branch and Branch mapping acceleration can be immediately fulfilled with reliable output output, so that it impacts on the Muhammadiyah business charity governance model based on Information Systems Management in the region Bandung city PDM can be more developed.

\section{SUGGESTION}

- Conduct SICARA Application socialization, training, and workshop involving Branches and Branches because developing the SICARA Application requires the active role of all Branches and Branches.

- Continue to update and develop the SICARA Application to be consistent so that the main objective of Branch and Branch acceleration can be resolved immediately with reliable results. 


\section{REFERENCES}

[1] Michael D Mehta, "Good Governance", dalam Mark Bevir, Encyclopedia of Governance, hal. 359-262

[2] IT Governance Institute (2000), “COBIT 3rd Implementation Tol Set", IT Governance Institute.

[3] https://www.republika.co.id/berita/nasional/umum/15/08/06/nsnso 9361-alasan-mengapa-amal-usaha-muhammadiyah-bisa-ditanganinonmuslim $(10 / 08 / 2019,13.00 \mathrm{WIB})$

[4] Jogiyanto. 2003. Sistem Teknologi Informasi. Andi. Yogyakarta.

[5] Alter, Steven, 1992, "Information Systems: A Management Perspective", The Benjamin/ Cumming Publishing Company, Inc.

[6] Calder, Alan and Watkins, Steve. 2008. " IT GOVERNANCE - A Manager's Guide to Data Security and ISO27001/ISO 27002. Kogan Page. United States.

[7] Lucas, Henry J., 2000. "Information Technology for Management." The 7th edition, Irwin/ Mc Graw Hill.

[8] Abu-Musa, A.A. 2007, "Exploring Information Technology Governance (ITG) in Developing Countries", The International Journal of Digital Accounting Research, vol.7,n.13,pp.69-114.

[9] Khadra H.A., Zuriekat M., and Alramhi N., 2009. "An Empirical Examination of Maturity Model as Measurement of Information Technology Governance Implementation." The International Arab Journal of Information Technology, vol.6, no.3, July 2009.

[10] http://raghibnuruddin217.blogspot.com/ (10/03/2020, 15.11WIB)

[11] https://SICARA.id (10/03/2020, 21.01WIB)

[12] http://lpcr.muhammadiyah.or.id/ (10/03/2020, 23.43WIB)

[13] Panduan SICARA yang didownload dari Aplikasi SICARA, https://SICARA.id

[14] R E L E (Rekayasa Elektrikal dan Energi) : Jurnal Teknik Elektro Vol. 2, No. 1, Juli 2019 ISSN 2622 - 7002, Partaonan Harahap, Sudirman Lubis, Cholish; Pelatihan Pembuatan Peta Cabang Dan Ranting Muhammadiyah Menggunakan Aplikasi SICARA Untuk Mercepatan Pemetaan Cabang Dan Ranting Muhammadiyah SeKota Medan, Universitas Muhammadiyah Sumatera Utara (UMSU) 